\title{
Traditional Political Institutions and Democracy: Reassessing Their Compatibility and Accountability
}

Comparative Political Studies 2019, Vol. 52(12) 1747-1774

(C) The Author(s) 2019

Article reuse guidelines: sagepub.com/journals-permissions DOI: $10.1177 / 0010414019852686$ journals.sagepub.com/home/cps

(9SAGE

\section{Kate Baldwin' ${ }^{1}$ and Katharina Holzinger ${ }^{2}$ (ID}

\begin{abstract}
This article revisits prominent frameworks for understanding traditional political institutions which make pessimistic assessments about their compatibility with democracy. Traditional political institutions are often assumed to be unaccountable because they are led by undemocratic leaders who are not subject to electoral sanctioning. However, drawing on new information from the TradGov Group dataset, an expert survey on the contemporary practices of more than I,400 ethnic groups that currently have traditional political institutions, we show that these institutions contain their own distinct mechanisms of accountability. In a majority of cases, decision-making is consensual and leaders must account for their actions in various ways. We challenge the electoral accountability framework for understanding the quality of traditional leaders' performance, instead arguing that traditional political institutions can be compatible with democracy and even accountable to their citizens insofar as they adopt inclusive decisionmaking processes and their leaders have strong nonelectoral connections to the communities they represent.
\end{abstract}

\footnotetext{
'Yale University, New Haven, CT, USA

2University of Konstanz, Germany

\section{Corresponding Author:}

Kate Baldwin, Peter Strauss Family Assistant Professor, Department of Political Science, Yale University, I I 5 Prospect Street, P.O. Box 20830 I, New Haven, CT 06520, USA. Email: katharine.baldwin@yale.edu
} 


\section{Keywords}

traditional political institutions, traditional leaders, democracy, accountability, state building

\section{Introduction}

This article introduces a special issue examining the relationship between traditional political institutions and democracy in the contemporary world. In recent years, a number of scholars have noted the persistence and even resurgence of traditional political institutions, especially in sub-Saharan Africa (Englebert, 2002; Logan, 2009, 2013; Muriaas, 2011; Ubink, 2008), but also in Latin America (Díaz-Cayeros, Magaloni, and Ruiz-Euler, 2014), Central Asia (Murtazashvili, 2016), and South-East Asia (Henley \& Davidson, 2008). This has been thought to be a challenge for democracy by many authors (Acemoglu, Reed, \& Robinson, 2014; Mamdani, 1996; Ntsebeza, 2005).

What are traditional political institutions? We define them broadly as institutions whose legitimacy is based in part on their association with customary modes of governing a community. These institutions are political in the sense that they make decisions regulating and providing for the collective, and they are traditional in the sense that they are popularly believed to be connected to custom. ${ }^{1}$ We emphasize that these institutions are associated with custom in the popular imagination, not that they are accurate reflections of historic governance practices (Ranger, 1983). Traditional political institutions encompass a wide range of entities, from village-level shura councils in Afghanistan to the Zulu monarchy in South Africa.

In the absence of comparative empirical data on the existence and the characteristics of traditional political institutions, the study of these institutions has been heavily driven by theoretical expectations derived from the prominent frameworks used to study traditional political institutions. For the most part, these theoretical frameworks have been pessimistic about the compatibility of traditional institutions and modern democratic states. For example, modernization theory contrasts traditional political institutions with an ideal type of rationalized bureaucratic authority (Huntington, 1968; Lerner, 1958). A major strand of democratic theory emphasizes the role of elections in creating accountability, implying unelected traditional institutions are likely to provide poor leadership (Barro, 1973; Besley \& Burgess, 2002; Ferejohn, 1986; Manin, Przeworski, \& Stokes, 1999; Schumpeter, 1942). Theories of clientelism suggest that traditional leaders can make politicians less accountable to citizens by serving as vote brokers who drum up electoral support via coercion and contingent exchanges (Lemarchand \& Legg, 1972). 
As a result, the conventional wisdom has been that traditional institutions restrict the individual rights of citizens and inhibit the development of democratic states (Hariri, 2012; Mamdani, 1996; Ntsebeza, 2005). Some scholars have challenged these claims with empirical evidence suggesting the compatibility of traditional institutions and democracy (Logan, 2013; Oomen, 2005; Osabu-Kle, 2000). But only in very recent years has a literature emerged that makes the counterargument that traditional leaders can serve citizens' interests by helping to broker government resources and/or coordinating collective action (Baldwin, 2016b; Honig, 2019; Murtazashvili, 2016).

The special issue which this article introduces is motivated by the discrepancies between prominent theoretical frameworks for understanding traditional leaders and recent empirical evidence. The articles that make up the special issue seek to assess the compatibility of traditional institutions with democratic institutions as an empirical matter and the ability of democratic theory to explain their empirical performance. Drawing on evidence from around the world, the contributions shed light on two questions. First, can traditional political institutions be compatible with modern democratic states? Second, in the absence of electoral accountability, can the responsiveness of traditional political institutions to their constituents be explained by democratic theory?

In this introductory article, we provide a critical assessment of prominent theoretical frameworks for understanding traditional political institutions in political science, which have emphasized their incompatibility with democracy. First, we argue that the application of these theoretical frameworks has often resulted in a mischaracterization of traditional institutions. Drawing on a new global dataset from the TradGov group at the University of Konstanz, we provide evidence on the existence and characteristics of contemporary traditional political institutions. Traditional political institutions are pervasive, affecting at least one quarter of the world's population, the majority of which live in semidemocratic or democratic states. But critically, even if the majority of traditional political institutions do not use regular elections to select leaders, the vast majority do contain mechanisms of nonelectoral accountability.

Second, we argue that prominent theoretical approaches overstate the incompatibility of traditional political institutions with democracy, and we challenge the use of electoral accountability as a framework for understanding the responsiveness of traditional political institutions. As our review of empirical evidence in the next two sections shows, traditional leaders perform better than would be theoretically expected given the limited role of elections in selecting and sanctioning them. The varying effectiveness of traditional institutions is also poorly explained by drawing parallels between 
features of their appointment process and standards for free and fair elections; the landmark study by Acemoglu et al. (2014) finds, against the authors' expectations, that chiefs are more popular and more active in providing local public goods when they are selected through less competitive processes.

Instead, we emphasize the importance of nonelectoral accountability in explaining the performance of traditional political institutions. As the TradGov Group survey data show, in a majority of traditional political institutions, decision-making is consensual and leaders must account for their actions by publicly justifying them. Instead of measuring the extent to which processes of selecting traditional leaders approximate competitive elections to understand their performance, we propose focusing on the extent to which these institutions have inclusive decision-making processes and their leaders have strong nonelectoral connections to their constituents. Inclusive institutions and strong local connections may take distinct forms in different contexts; connections may be the result of dense social ties, demographic similarities, or long relationships that create aligned interests between leaders and citizens.

In this introductory article, we set the stage for the remaining research articles by providing some critical background facts and a survey of existing empirical research. In the next section, we provide new data from the TradGov Group expert survey on the existence and characteristics of traditional political institutions worldwide. In the review section, we summarize the dominant theoretical frameworks used to assess the compatibility of traditional institutions with liberal democracy, and we discuss the limited evidence marshaled to date to test these frameworks. In the subsequent section, we provide our revised perspective on (a) the relationship between traditional institutions and democracy and (b) the ability of democratic theory to explain the responsiveness of traditional institutions. This section draws on the empirical findings from the research articles to emphasize the importance of nonelectoral mechanisms of accountability, especially the inclusivity of decision-making processes and the strength of leaders' connections to their communities. Yet, though we think the findings of this special issue are compelling in challenging long-held assumptions, much additional empirical research is necessary in this area. The final section concludes by outlining our recommendations for future research directions.

\section{Traditional Political Institutions in the Contemporary World}

At the outset of this special issue, we provide some descriptive information on the relevance of traditional governance in the contemporary world. What 
percentage of the world's population lives in traditionally organized communities and how are these groups distributed across the world? To what degree do we find them in democracies and autocracies? And, finally, how democratic or autocratic are their traditional political institutions? The dispute about whether traditional institutions undermine democracy (prominently Mamdani, 1996; Ntsebeza, 2005) or even strengthen it (e.g., Logan, 2013; Baldwin, 2016; cf. Holzinger, Kern, \& Kromrey, 2016 for a review) has mostly concentrated on sub-Saharan Africa. In other regions, there has been much less study of traditional institutions.

This section draws on original data collected by Holzinger and her collaborators as part of a research project on traditional governance. To our knowledge, this is the first worldwide effort to collect data on the contemporary prevalence and characteristics of traditional institutions. These data were collected through a massive effort, including a systematic review of population data sources for 3,297 potentially traditionally organized groups and an online survey of 7,000 group experts, described in more detail below. ${ }^{2}$

We start by presenting estimates of the shares of the population that is governed by traditional governance institutions in the contemporary world. These are best estimates based on the TradGov Group dataset. To construct these estimates, we compiled a list of 3,297 potentially traditionally organized groups in $152 \mathrm{UN}$ countries. This list was informed by provisions on traditional institutions in constitutions taken from the TradGov Constitutional dataset, the Ethnic Power Relations dataset (EPR, Cederman et al., 2010), and the All Minorities at Risk dataset (AMAR, Birnir et al., 2015). Following Kymlicka (1996), we concentrated on indigenous ethnic groups and removed the other EPR and AMAR groups. ${ }^{3}$ Then, we collected data on the population size of the remaining groups relying on all available sources. While the preferred source was a recent public census, in most cases we had to rely on encyclopedias or secondary sources. ${ }^{4}$ The data from these sources are not always comprehensive, sometimes even contradictory, and they do not always aggregate properly from subgroup to super-group. Nevertheless, the TradGov Group dataset provides the most up-to-date and encompassing indigenous ethnic group data currently available. Finally, to determine whether these groups in fact possess traditional political institutions in the contemporary period, we use data from an expert survey that provides information on 1,706 potentially traditionally organized groups (see details below). According to the judgment of these experts, 1,409 of these groups are in fact traditionally organized according to the standards set by our questionnaire, while the remaining 297 groups no longer possess any traditional institutions. $^{5}$ 
Table I. Share of Traditionally Organized Population (Percent of Population).

\begin{tabular}{lccc}
\hline Continent $^{\mathrm{a}}$ & Minimum share & Maximum share & Best estimate \\
\hline Sub-Saharan Africa & 69.43 & 84.16 & 83.83 \\
South and East Asia, Pacific & 18.80 & 48.64 & 37.65 \\
Middle East and North & 29.96 & 30.94 & 30.50 \\
Africa & & & \\
Europe and Central Asia & 6.80 & 8.61 & 7.60 \\
Americas, Caribbean & 5.71 & 6.25 & 6.05 \\
All UN member states & 23.32 & 42.00 & 35.78 \\
\hline
\end{tabular}

a. Continents based on World Bank categorization; we combine the Americas and South/East Asia; shares are continental population percentages.

Table 1 provides three figures. The minimum share indicates the average country population share of groups that experts identified as being traditionally organized (compared with groups identified as lacking traditional political institutions and groups with missing data). The maximum share indicates the population share that is potentially traditionally organized according to our list of 3,297 groups, subtracting the population share of groups that experts indicated were not (or no longer) traditionally organized. The best estimate assumes the share of the population that is traditionally organized is the same for groups with and without missing data in the expert survey.

Across all countries, an average of $36 \%$ of the population has traditional political institutions according to our best estimate, with a range from $23 \%$ to $42 \%$. These are considerable numbers: even if we conservatively assume the minimum share, almost one quarter of the world's population is affected by our topic. We find most of the traditionally organized communities in subSaharan Africa, followed by South/East Asia and the Middle East/North Africa. While traditionally organized groups are almost inexistent in Europe, we find them to some degree in Central Asia and the Americas.

How are these traditionally organized communities distributed across democracies and autocracies? How do democracies and autocracies acknowledge traditionally organized communities and to what degree do they integrate them legally? As a first indicator of legal integration, we use information on the representation of traditional institutions in constitutions. The constitutions of 94 out of 193 UN member states recognize indigenous rights, customary law, and/or traditional authorities (TradGov Constitutional dataset, cf. Holzinger, Haer, Bayer, Behr, \& Neupert-Wentz, 2019, in this special issue).

To understand how groups with traditional political institutions interact with democratic governments, we cross-tabulate traditional population and 
Table 2. Traditionally Organized Population and Constitutional Provisions Across Democracy Categories, 2014.

\begin{tabular}{lcccccc}
\hline & $\begin{array}{c}\text { Polity2 } \\
\text { autocracy }\end{array}$ & $\begin{array}{c}\text { Polity2 } \\
\text { anocracy }\end{array}$ & $\begin{array}{c}\text { Polity2 } \\
\text { democracy }\end{array}$ & $\begin{array}{c}\text { FH not } \\
\text { free }\end{array}$ & $\begin{array}{c}\text { FH partly } \\
\text { free }\end{array}$ & $\begin{array}{c}\text { FH } \\
\text { free }\end{array}$ \\
\hline $\begin{array}{c}\text { Traditionally } \\
\text { organized } \\
\text { population }\end{array}$ & 28.91 & 62.78 & 26.08 & 54.57 & 48.28 & 14.88 \\
$\begin{array}{c}\text { Constitutional } \\
\text { provisions }\end{array}$ & 19.05 & 45.10 & 29.35 & 33.33 & 51.85 & 21.59 \\
$\begin{array}{c}\text { No. of } \\
\text { countries }\end{array}$ & 21 & 51 & 92 & 51 & 54 & 88 \\
\hline
\end{tabular}

$\mathrm{FH}=$ Freedom House.

a. Average population share (mean of country shares), based on best estimate from Table I.

b. Includes provisions on traditional political institutions or customary law; dichotomous.

constitutional recognition with the democracy categories of Polity IV and Freedom House (FH). We use 2014 data as these correspond to the latest year of the constitutional data. ${ }^{6}$

Table 2 provides both the percentage of the population that is organized in traditional institutions and the percentage of constitutions that acknowledge traditional political institutions or customary law by regime type. For example, the first column shows that, on average, $29 \%$ of the population in Polity IV autocracies is organized traditionally and $19 \%$ of Polity IV autocracies have constitutional provisions for either traditional political institutions or customary law. We find traditionally organized groups are less common in countries that are fully democratic (or free), but most traditionally organized groups exist in countries that are at least partly free (semidemocratic). With respect to constitutional acknowledgment, the pattern shifts somewhat: Democratic and free countries have a higher share of constitutions that acknowledge traditional organizations than would be expected given the share of their populations that are traditionally organized (and vice versa for autocracies and anocracies). ${ }^{7}$

These statistics make two critical points about the compatibility of traditional political institutions and democracy. First, a significant number of people live in communities governed by both traditional political institutions and democratic governments. As an empirical matter, democratic and traditional institutions frequently coexist, even if traditional political institutions are more prevalent in nondemocracies. Second, traditional institutions are more likely to have constitutional recognition in more democratic countries. This suggests that democratically elected governments frequently view 
traditional political institutions as potentially compatible and are willing to respond to their presence by integrating them into the state legal system. This result complements the findings of the contribution by Holzinger et al. (2019) in this issue.

The evidence in Table 2 suggests traditional political institutions often coexist with democratic institutions, but a deeper examination of their compatibility requires consideration of how traditional political institutions operate. Do these institutions operate on nondemocratic principles? Turning to this question, we provide new information on the organization of traditional political institutions. Based on the list of 3,297 potentially traditionally organized groups, almost 7,000 group experts were invited to respond to a web survey containing 25 questions, offered in English, French, Spanish, Portuguese, and Russian. ${ }^{8}$ With a response rate of $42 \%$ and an average of 1.63 experts per group, the dataset covers 1,706 distinct groups in $147 \mathrm{UN}$ countries, ${ }^{9}$ of which 1,409 possess some form of traditional political institution. The following tables are based on the expert responses for these 1,409 groups.

Three questions from the expert survey deal with democratic accountability and democratic decision-making in traditional institutions. The first asks whether traditional leaders are elected or come into office by other mechanisms, the second asks for mechanisms of accountability more generally, and the third asks for decision rules within traditional bodies, such as councils or assemblies. As the three questions allow for multiple response, the data indicate the share of survey groups which possess a certain type of traditional leader (or governance body) for which the experts report a given response category. The experts were asked to respond with respect to the contemporary practices of their respective expertise groups. ${ }^{10}$

Table 3 displays the responses to the question about leadership selection mechanisms within traditionally organized groups with kings, chiefs, and headmen. While $77 \%$ of groups with kings use inheritance for selection, $23 \%$ use election, $32 \%$ use appointment by other traditional leaders, and $25 \%$ use rotation among clans or families. For groups with headmen, the corresponding figures indicate less use of inheritance and greater use of elections. Thus, inheritance is not the only or even predominant selection mechanism. Both election and rotation are commonly used, allowing for some change in power, with elections more frequently used for lower level leaders. It is important to note that the mechanisms are not exclusive; for example, appointment can be used in combination with the other selection processes. More generally, this question cannot distinguish between the "real" selection mechanism and additional (possibly) performative acts. For example, in Namibia traditional chiefs are selected based on clan membership and inherited roles. But they 
Table 3. Office of Traditional Leader: Selection Mechanism.

How does this leader of group $X$ come into his or her position?

\begin{tabular}{|c|c|c|c|c|c|c|c|}
\hline $\begin{array}{l}\text { Traditional } \\
\text { leader type }\end{array}$ & $\begin{array}{l}\text { Number of } \\
\text { groups with } \\
\text { leader type }\end{array}$ & Inheritance & Election & Appointment ${ }^{\mathrm{b}}$ & Rotation ${ }^{c}$ & Other & $\begin{array}{c}\text { Do not } \\
\text { know }\end{array}$ \\
\hline \multicolumn{8}{|c|}{ King/Queen/Paramount Chief/Emir ${ }^{d}$} \\
\hline$\%$ e & & 77 & 23 & 32 & 25 & 9 & I \\
\hline$n$ & 341 & 261 & 78 & 109 & 85 & 30 & 2 \\
\hline \multicolumn{8}{|c|}{ Chief/Khan/Ariki/Jif ${ }^{d}$} \\
\hline$\%$ e & & 55 & 29 & 33 & 20 & 10 & 5 \\
\hline$n$ & 585 & 322 & 167 & 192 & 116 & 59 & 27 \\
\hline \multicolumn{8}{|c|}{ Headman/Bandleader } \\
\hline$\%$ e & & 45 & 33 & 31 & 15 & 12 & 8 \\
\hline$n$ & 597 & 267 & 197 & 183 & 92 & 74 & 48 \\
\hline
\end{tabular}

a. Number of groups for which the experts report they have the respective traditional leader. b. By other traditional leaders. c. Among families or clans, as in age-set systems. d. Synonyms explained in filter question, type of traditional leader relates to hierarchical levels. e. Percentage of groups for which the experts report they use the selection mechanism (multiple response).

also need to be acknowledged by their peers in the National Council of Traditional Leaders, the president and the "Ministry of Regional and Local Government, Housing and Rural Development"-which leads to conflict in some cases (Holzinger, Kern, \& Kromrey, 2017, p. 22).

Table 4 indicates that softer accountability mechanisms prevail over harder ones in traditional institutions. Softer mechanisms, such as justification of action and apology, amount to almost half of the responses. However, experts report that leaders are forced to step down (by whichever practical action) if their decisions are disapproved of by the constituency in around $30 \%$ of the groups at all three hierarchical levels. Leaders can be voted out of office in $8 \%$ of groups with kings and $16 \%$ of groups with lower level leaders, indicating the possibility of losing office for poor performance in a significant number of cases. Across the levels, $19 \%$ to $9 \%$ of the groups are said to apply no accountability mechanism. Thus, we cannot infer from these numbers that traditional political institutions come without any accountability (see also the contributions of Baldwin, 2019, and Magaloni, Díaz-Cayeros, \& Ruiz-Euler, 2019, in this special issue). In general, there is a tendency for accountability mechanisms to be stronger at lower levels of the traditional hierarchy. Soft accountability mechanisms, such as justification of action, are more likely to be required when leaders are more accessible to their communities and more socially embedded. 
Table 4. Office of Traditional Leader: Accountability Mechanism.

How is the leader of group $X$ held accountable by the members of that group for decisions they disapprove of?

\begin{tabular}{|c|c|c|c|c|c|c|c|c|}
\hline $\begin{array}{l}\text { Traditional } \\
\text { leader } \\
\text { type }\end{array}$ & $\begin{array}{l}\text { Number of } \\
\text { groups with } \\
\text { leader type }\end{array}$ & $\begin{array}{l}\text { Justification } \\
\text { of action }\end{array}$ & $\begin{array}{l}\text { Forced } \\
\text { to step } \\
\text { down }\end{array}$ & Apology & $\begin{array}{l}\text { Other } \\
\text { sanction }\end{array}$ & $\begin{array}{l}\text { Voted } \\
\text { out of } \\
\text { office }\end{array}$ & $\begin{array}{c}\text { No } \\
\text { accountability }\end{array}$ & $\begin{array}{l}\text { Do not } \\
\text { know }\end{array}$ \\
\hline \multicolumn{9}{|c|}{ King/Queen/Paramount Chief/Emirb } \\
\hline$\% c$ & & 35 & 32 & 24 & 20 & 8 & 19 & 10 \\
\hline$n$ & 341 & 120 & 110 & 82 & 70 & 27 & 64 & 35 \\
\hline \multicolumn{9}{|c|}{ Chief/Khan/Ariki/Jif } \\
\hline$\%^{c}$ & & 38 & 29 & 24 & 21 & 12 & 11 & 15 \\
\hline$n$ & 585 & 224 & 172 & 138 & 125 & 68 & 62 & 85 \\
\hline \multicolumn{9}{|c|}{ Headman/Bandleader ${ }^{b}$} \\
\hline$\% c$ & & 39 & 33 & 25 & 21 & 16 & 9 & 14 \\
\hline$n$ & 597 & 230 & 196 & 147 & 127 & 95 & 55 & 81 \\
\hline
\end{tabular}

a. Number of groups for which the experts report they have the respective traditional leader. b. Synonyms explained in filter question, type of traditional leader relates to hierarchical levels. c. Percentage of groups for which the experts report they use the selection mechanism (multiple response).

What about decision-making rules within traditional political institutions? Here we asked the experts which decision rules apply in traditional bodies, independent of whether these have an advisory role (as is typical in king's councils) or decision-making powers (as is sometimes the case in village assemblies). Again, the possible use of different rules in different situations by the same body allows for multiple responses. Table 5 indicates the various bodies mostly make decisions by a consensus rule, with $55 \%$ of groups with king's councils using this practice and $70 \%$ of groups with councils of elders and assemblies. The second most common process is hierarchical decisionmaking, reported for $49 \%$ of groups with king's councils, but considerably less frequently for groups with lower level bodies. Least represented is the classical democratic decision rule, majority voting, present in between $17 \%$ and $24 \%$ of groups. The prevalence of rule by consensus points to the importance of inclusive decision-making, direct forms of democracy and deliberation as a way of obtaining collective decisions. Although hierarchical decision-making is important as well, we cannot infer from these data that traditional political institutions are per se autocratic.

Finally, we present data on the approval rates of traditional leaders compared with state political leaders from the last round of the Afrobarometer. ${ }^{11}$ Table 6 highlights that the approval of traditional leaders is generally higher (and disapproval correspondingly lower) as compared with the representative in the national assembly (MP), the president, and the local mayor (cf. the contribution of Magaloni et al., 2019, for a similar result in Mexico). The 
Table 5. Decision Rules in Traditional Bodies.

How are decisions generally made within the bodies?

\begin{tabular}{|c|c|c|c|c|c|c|}
\hline $\begin{array}{l}\text { Traditional } \\
\text { body type }\end{array}$ & $\begin{array}{l}\text { Number of } \\
\text { groups with } \\
\text { body type }\end{array}$ & Consensual & Hierarchical & $\begin{array}{c}\text { Majority } \\
\text { vote }\end{array}$ & $\begin{array}{l}\text { Other } \\
\text { way }\end{array}$ & $\begin{array}{l}\text { Do not } \\
\text { know }\end{array}$ \\
\hline \multicolumn{7}{|c|}{ King's councilb } \\
\hline$\% c$ & & 55 & 49 & 21 & 3 & 3 \\
\hline$n$ & 215 & 118 & 106 & 44 & 7 & 7 \\
\hline \multicolumn{7}{|c|}{ Council of elders ${ }^{b}$} \\
\hline$\% c$ & & 70 & 28 & 17 & 4 & 3 \\
\hline$n$ & 698 & 491 & 196 & 115 & 27 & 23 \\
\hline \multicolumn{7}{|c|}{ Traditional (village) assembly ${ }^{b}$} \\
\hline$\% c$ & & 70 & 25 & 24 & 5 & 4 \\
\hline$n$ & 749 & 526 & 188 & 181 & 34 & 29 \\
\hline
\end{tabular}

a. Number of groups for which the experts report they have the respective traditional body. b. Terminology explained in filter question and survey introduction. c. Percentage of groups for which the experts report they use the decision rule (multiple response).

only exception to this rule is a slightly higher rate of strong approval for the president $(21 \%)$ than for the traditional leader $(19.5 \%) .{ }^{12}$ The findings coincide with Logan's $(2009,2013)$ analyses of previous Afrobarometer survey rounds, which demonstrated the coexistence of traditional and modern democratic governance in Africa.

To summarize this section, traditional communities are present all over the world albeit to varying degrees across world regions, likely as a consequence of varying strategies of colonialism. A greater proportion of the population belongs to traditionally organized groups in anocracies and autocracies (or partly and not free countries). Nevertheless, traditional institutions are present in democracies as well, and democracies seem to offer relatively more legal integration. While traditional leaders and institutions are not elected in most traditional communities, we find other forms of accountability. Finally, at least for Africa, traditional leaders are considered to be performing well by their communities, and usually better than state politicians.

\section{Existing Theoretical Frameworks for Studying Traditional Institutions}

To date, traditional political institutions have largely been analyzed through frameworks that have had difficulty accounting for the empirical facts reviewed in the previous section. Scholars have tended to use one of three 
Table 6. Approval of Traditional and Political Leaders in Africa, 2016/2017.

Do you approve or disapprove of the way that the following people have performed their jobs over the past 12 months, or haven't you heard enough about them to say?

\begin{tabular}{lcccc}
\hline & $\begin{array}{c}\text { Traditional } \\
\text { leader }^{\mathrm{a}} \\
\text { \% respondents }\end{array}$ & $\begin{array}{c}\text { President } \\
\text { \% respondents }\end{array}$ & $\begin{array}{c}\text { Your member } \\
\text { of parliament }\end{array}$ \\
\% respondents & $\begin{array}{c}\text { Your mayor } \\
\text { \% respondents }\end{array}$ \\
\hline $\begin{array}{l}\text { Strongly } \\
\quad \text { disapprove }\end{array}$ & 10.0 & 17.1 & 20.7 & 13.5 \\
Disapprove & 14.1 & 19.3 & 28.5 & 23.6 \\
Approve & 44.2 & 37.0 & 32.3 & 36.9 \\
Strongly approve & 19.5 & 21.0 & 10.1 & 11.7 \\
Missing, unknown & 0.2 & 0.2 & 0.2 & 0.4 \\
Refused & 0.3 & 0.8 & 0.6 & 05 \\
$\begin{array}{l}\text { Do not know } \\
\text { No. of }\end{array}$ & 11.7 & 4.6 & 7.6 & 13.4 \\
respondents & 28,224 & 33,183 & 33,183 & 31,549 \\
\hline
\end{tabular}

Afrobarometer R7, 2016/2017.

a. Countries (italics: not included in traditional leader question): Benin, Botswana, Burkina, Cameroon, Cape Verde, Côte d'Ivoire, Gabon, Gambia, Ghana, Guinea, Kenya, Lesotho, Liberia, Madagascar, Malawi, Mali, Mauritius, Namibia, Niger, Nigeria, Sao Tome and Principe, Senegal, Sierra Leone, South Africa, Sudan, Swaziland, Tanzania, Togo, Tunisia, Uganda, Zambia, Zimbabwe.

lenses to study traditional leaders - the frameworks of Weberian legal-rational authority, patron-client relationships, or electoral accountability-which has led to pessimistic views about their compatibility with democracy and their accountability. In this section, we assess these frameworks in view of recent empirical evidence.

\section{Framework I: Traditional Authority in Contrast to Legal-Rational Authority}

The first common framework used to understand traditional leaders is Weber's typology of authority (Weber, 1958). In this typology, traditional authority is explicitly conceived as an alternative to legal-rational authority. In contrast to the latter system, where outcomes are the result of well-defined law that applies equally to all, under traditional authority, power is based on connections to the ruler and appeals to custom. Insofar as these ideal types are conceived as exclusive of one another, this framework predicts traditional 
institutions will limit the rights of citizens, augment biases against historically marginalized groups, and undermine the rule of law. Similar predictions emerge from recent research that models customary justice systems as having built-in biases against marginalized groups and emphasizing the restoration of social order above punishment for violation of individual rights (Aldashev et al., 2012; Cooper, 2018; D’Aoust \& Sterck, 2016).

Insofar as equal rights and established rule of law are necessary for democracy (O'Donnell, 1993), these theoretical frameworks make pessimistic assessments about the effects of traditional institutions on democracy. Citizens living under traditional leaders become "subjects" not "citizens," to use the terminology of Mamdani (1996). They are expected to have limited recourse against abuses of power and limited protections from predation by the state or other citizens. Research in this vein has focused on documenting shortcomings of traditional institutions compared with an ideal of equal rights for all. In particular, scholars have documented the weak rights provided to marginalized groups, especially women, under traditional systems (Chanock, 1985; Charrad, 2001). Other marginalized groups have also been found to have weak protections in traditional systems. For example, in Zimbabwe, Baldwin, Muyengwa, and Mvukiyehe (2016) show that reforming traditional institutions so they are more inclusive improves the rights of the chiefs' opponents.

There have been relatively few studies examining whether traditional institutions perform comparatively worse than alternative institutions in providing individuals with rights and protecting them from exploitation. In Liberia, women in disputes with men tend to opt out of the customary system if they are given access to legal aid and they are happier with the results of their cases when they do (Sandefur \& Siddiqi, 2013). Similarly, in Papua New Guinea, the creation of community police as an alternative method of dispute resolution is viewed more favorably by women than by men, and women are more likely to exit the traditional justice system when given the option (Cooper, 2018). In Afghanistan, the creation of gender-inclusive village development committees improves citizens' attitudes toward women's political participation compared with communities where they do not exist (Beath, Christia, \& Enikolopov, 2013b). All of these studies suggest that women's rights are weaker under traditional governance institutions compared with progressive institutions.

However, in other settings, customary institutions have been found to perform better than existing alternatives in protecting women's rights and establishing rule of law. For example, in Afghanistan, citizens express stronger support for women's rights in villages where traditional shuras are strong (Murtazashvili, 2016). Afghani citizens also expect customary councils to 
perform better than elected councils in reducing social divisions and furthering reconciliation, suggesting traditional institutions may in some instances outperform alternatives in providing rule of law (Jochem, Murtazashvili, \& Murtazashvili, 2016). These latter findings indicate the problem with frameworks that assume traditional institutions always perform worse than alternative institutions in protecting rights. Their relative performance will depend on both their own quality and the quality of the alternative. Traditional authorities are not always regressive, and modern alternatives are not always egalitarian. Dualistic frameworks, such as Weber's, obscure important variation.

\section{Framework II: Traditional Leaders as Clientelist Brokers}

The second framework frequently used to analyze traditional institutions is the framework of electoral clientelism. Early conceptual work compared traditional leaders with brokers in political machines, arguing that they could use coercion, deference, and material inducements to mobilize support for their preferred political candidates (Lemarchand \& Legg, 1972; Scott, 1972). Traditional leaders were conceived as particularly important local patrons who could draw on varied sources of symbolic and material power to deliver vote blocks (Cruise \& Brien, 1971; Lemerchand, 1972). This framework also predicts traditional leaders to have detrimental effects on democracy. By serving as clientelist brokers, they are predicted to cause citizens to vote against their political interests and to hinder the development of programmatic politics (Keefer \& Vlaicu, 2008; Stokes, 2007).

Yet despite widespread concerns about traditional leaders acting as electoral brokers, there is limited empirical evidence that they can exert power over other voters. One piece of evidence comes from South Africa, where former Bantustans, which have stronger traditional leaders, also have significantly higher levels of support for the incumbent party (De Kadt \& Larreguy, 2018). In contrast, traditional leaders elsewhere in Africa have been found to have limited influence over voters. In Senegal, only small numbers of voters coordinate on outcomes that are in the interest of traditional brokers, rather than on outcomes that are in citizens' own best interests (Gottlieb, 2017). In Zambia, few voters change their political preferences based on their chiefs' opinions (Baldwin, 2013).

Furthermore, when traditional institutions do play a role in convincing and coordinating voters during elections, it is not clear that it results in democratically less desirable outcomes. For example, the existence of hierarchical traditional institutions can dampen ethnic politics in sub-Saharan Africa, allowing politicians to make credible cross-ethnic appeals via traditional 
leaders (Baldwin, 2014; Koter, 2013). Strong traditional institutions may even help citizens coordinate on candidates who provide public goods rather than relying on clientelist exchanges; political endorsements from traditional leaders help citizens select candidates who perform better in delivering local public goods in Zambia (Baldwin, 2013), and there is less vote buying in places with hierarchical traditional institutions across sub-Saharan Africa (Kramon, 2017).

Thus, the empirical evidence suggests traditional institutions sometimes broker the relationship between citizens and the state. But the classic model of clientelism cannot explain the contexts in which they do so and it does not shed light on the range of ways that these institutions can act to organize citizens' interests in contemporary politics.

\section{Framework III: Traditional Authorities as Unelected Leaders}

The third common framework used to understand traditional leaders is that of electoral accountability. Contemporary democratic theory places special importance on the role of elections in creating accountability and disciplining leaders (Barro, 1973; Besley \& Burgess, 2002; Ferejohn, 1986; Manin et al., 1999; Schumpeter, 1942). Elections are thought to result in good leadership both because they allow voters to select the best individual from multiple options and because they allow them to get rid of poorly performing leaders (Fearon, 1999). In contrast, unelected leaders are predicted to have lower skills on average and to lack electoral incentives to govern well. Viewed through this theoretical lens, traditional leaders are expected to be both undemocratic and poor performers because they are rarely subject to regular election.

As an empirical matter, most traditional leaders are undemocratic in the sense that most of them are not subject to periodic election, as shown in the previous section. But how important is electoral accountability in explaining the leadership performance of traditional leaders? This theoretical framework sits uncomfortably with the finding that traditional leaders are often given high performance grades, even compared with elected leaders as shown in the previous section (cf. Logan, 2013). To empirically evaluate the explanatory value of this framework, two types of comparisons are relevant-comparisons of traditional leaders selected through more competitive processes to traditional leaders selected through less competitive processes, and comparisons of unelected traditional leaders to elected leaders who are otherwise similarly situated.

Just a handful of recent studies have compared the performance of traditional leaders selected through more or less competitive processes. The main 
evidence comes from Acemoglu, Reed, and Robinson (2014)'s study in Sierra Leone, which finds that chiefdoms with more ruling families, thereby ensuring a more competitive selection process, have higher land sales and higher economic development. However, against expectation, they also find that competitively selected chiefs are less likely to coordinate community contributions to local public goods, such as road brushing. Similarly, Liberian chiefs selected through more competitive processes have been found to be worse at ensuring public order and at organizing contributions in a public goods game (Baldwin \& Mvukiyehe, 2015), and Zambian chiefs chosen through more inclusive selection processes are more likely to prioritize private goods over public goods (Baldwin, 2016a). Thus, on some dimensions, traditional leaders selected through processes that induce more electoral competition perform worse than their counterparts who face less competition. One plausible explanation is that the competitiveness of the process for selecting leaders is inversely related to the strength of leaders' connections to their communities; competition may be the result of no leader having strong societal connections.

In considering the importance of electoral accountability in disciplining traditional leaders, comparisons of decision-making and public goods provision across different authorities are also relevant. Do traditional institutions perform worse than similarly situated institutions in which leaders are selected through competitive elections? The evidence here is also very limited. ${ }^{13}$ In Afghanistan, villages with established customary institutions have fewer disputes than villages with elected community-development councils (Murtazashvili, 2016). In the same context, a field experiment found no differences in embezzlement or community participation in villages in which newly formed, elected community-development councils were given the power to distribute food aid and villages in which traditional councils were asked to distribute this aid; however, traditional councils were worse at targeting objectively vulnerable households (Beath et al., 2013a). In Mexico, villages with traditional institutions incorporating elements of participatory democracy perform better than villages with competitive party competition in the provision of some local public goods (Díaz-Cayeros et al., 2014).

Together, these studies hint at the limitations of trying to understand how accountable and democratic traditional institutions are through the lens of electoral accountability. In some instances, traditional institutions perform better than similarly situated elected institutions. The varied performance of traditional institutions does not appear well explained by how closely their procedures for selecting leaders approximate competitive elections. Furthermore, in instances in which traditional institutions do incorporate democratic procedures, participatory decision-making processes and soft 
accountability mechanisms backed up by social pressure would appear more important than the periodic election of leaders. The TradGov Group survey data indicate that alternative accountability mechanisms are present in traditional settings, especially when leaders are more closely connected to their constituents. This suggests the need to move beyond the lens of electoral accountability to understand when and why traditional institutions are more or less responsive.

\section{A Revised Perspective on Traditional Institutions}

The dominant existing frameworks for understanding traditional institutions emphasize fundamental incompatibilities between these institutions and democratic ideals. However, the empirical facts and research reviewed in the previous two sections suggest that traditional institutions have more complicated relationships with democracy and accountability than these frameworks would predict. In view of this, the goals of this special issue are twofold. First, we aim to assess the empirical compatibility of traditional institutions with modern democratic states. Second, we aim to challenge the electoral accountability framework for understanding the quality of traditional leaders' performance. Instead, we argue that the inclusivity of decision-making practices and the nonelectoral connections of leaders to their constituents are more useful frameworks for understanding the influence and performance of traditional institutions.

Our first claim is that traditional institutions are compatible with modern democratic states in the sense that they can empirically coexist and can be legally and politically integrated. The first two articles in the special issue provide distinct types of evidence in support of this claim, overcoming two major challenges to making the assessment. The study of the relationship between states and traditional political institutions has been hindered by both the lack of comprehensive cross-national data on traditional institutions and the difficulty of drawing causal claims based on observed correlations. The first article by Holzinger et al. (2019) overcomes the first data challenge through an original data collection effort on indigenous rights, customary law, and traditional political institutions for all UN member states. The second article by van der Windt, Humphreys, Medina, Timmons, and Voors (2019) tackles the second inferential challenge by providing an estimation strategy for identifying how demand for traditional political institutions and demand for state institutions relate.

Holzinger et al. (2019) provide a comprehensive study of the constitutional acknowledgment of indigenous rights, customary law, and traditional political institutions. This is, to our knowledge, the first study to attempt a 
global comparison of traditional political institutions. Drawing on crossnational multivariate regressions, the authors find no evidence that democratic states have less recognition of traditional groups and institutions than their nondemocratic counterparts. They demonstrate that democratic states are significantly more likely to acknowledge indigenous group rights than undemocratic states, but do not find a significant relationship with constitutional acknowledgment of traditional political institutions or customary law. Nevertheless, many democracies integrate traditional institutions in their state-level constitutional setup, for example, by lower chambers representing traditional authorities (Botswana, Ghana, Namibia, Zambia). Instead, the constitutionalization of traditional political institutions and customary law is mainly correlated with high ethnic diversity and low metropolization.

van der Windt et al. (2019) make a different type of contribution, providing a critical conceptual and inferential advance in understanding whether traditional institutions and state institutions are viewed by citizens as substitutes or complements. The authors argue that the compatibility between these two sets of institutions cannot be inferred from correlations between levels of support for traditional leaders and the state. To learn whether these institutions are substitutes or complements in the minds of citizens requires exploring an elasticity of substitution: the extent to which support for one institution rises or falls with a change in the valuation of the other. They develop a structural model that allows them to estimate this elasticity using plausibly exogenous shocks to these institutions' valuations caused by conflict and abnormal rainfall in the Democratic Republic of Congo. The data show that citizens' views of the state and traditional chiefs are negatively correlated, which may be taken as prima facie evidence for rivalry and the logic of substitution. When they estimate the elasticity of substitution, however, they find that an increase in the valuation of the state increases the support for the chief. Citizens thus perceive traditional and modern (semidemocratic) authorities as complementary actors embedded in the same integrated system.

Our second claim is that the performance of traditional institutions is not well explained using the framework of electoral accountability. Traditional institutions do not perform systematically worse in providing local public goods and protecting individuals' rights than institutions in which leaders are selected through more competitive processes. Furthermore, we downplay the importance of competition in explaining variation in the authority and performance of traditional institutions. Instead, we emphasize the importance of inclusive decision-making processes and strong nonelectoral connections between traditional leaders and their constituents that align their interests, whether these connections are the result of dense social ties, demographic 
similarities, or durable relationships. The last three articles in the special issue provide evidence on these points, comparing the performance of competitively elected authorities and traditional authorities in Mexico, Malawi, and Zambia.

The article by Magaloni et al. (2019) compares the performance of municipalities in which mayors are selected through competitive multiparty elections to those governed by traditional assemblies, called usos y costumbres in Oaxaca, Mexico. In the latter communities, mayors are selected through nonpartisan (typically public) votes in community assemblies. Ethnographic research indicates that these mayors are constrained by the fact that-compared with partisan politicians - they have a higher expectation of living in the community after their term ends (and even serving another term in office), and by the strong norms of public deliberation associated with usos y costumbres. Using both survey data and administrative data analyzed through a geographic discontinuity approach, the authors find that indigenous communities governed through traditional institutions are more progressive in their distribution of water and sewerage and that they provide water to more citizens.

The article by Muriaas, Wang, Benstead, Dulani, and Rakner (2019) compares the authority of male and female traditional leaders and MPs in protecting the rights of children. Traditional leaders in Malawi typically inherit their positions, while MPs are elected in multiparty elections. The vast majority of traditional leaders and parliamentarians are male, but at the time of this study, there were a number of female chiefs ( 25 in total, for $10 \%$ of all traditional authorities) and female MPs (33 in total, for $17 \%$ of all MPs). Drawing on evidence from a survey experiment in Malawi in which respondents were randomly assigned to hear endorsements from male or female traditional leaders and MPs, they find that female traditional leaders are the only leaders who, in the sample as a whole, do not elicit a negative backlash when speaking out against child marriage, and that they are particularly effective vis-àvis other leaders in matrilineal communities and among women. These results indicate that elected leaders do not have systematically greater authority than traditional leaders in Malawi, and they underscore the importance of community norms and traditional authorities' demographic positions in influencing their authority.

The final article by Baldwin (2019) compares the effectiveness of hereditary chiefs and elected MPs in organizing locally funded public goods in Zambia. Specifically, the analysis compares the effects of leadership vacancies for chiefs and MPs caused by the death of the previous office holder. The article shows that deaths of chiefs cause significant reductions in the provision of local public goods funded in part by community contributions, but deaths of MPs do not. Across chiefdoms, community contributions are 
highest when the chief has the longest expectations about the length of their tenure. This highlights the importance of long time horizons in generating accountable leadership by traditional chiefs, a point also suggested by Magaloni et al. (2019).

Together, these studies demonstrate that there are many contexts in which traditional leaders govern relatively well, despite the absence of electoral incentives to do so. Their authority is not primarily based on electoral legitimacy, and their performance is not well explained by frameworks that emphasize political competition. Instead, these articles suggest the authority and performance of traditional institutions is better explained by the inclusivity of decision-making processes in traditional political institutions and the strength of traditional leaders' connections to their constituents.

\section{Areas for Future Research}

The study of traditional political institutions has only recently regained the attention of political scientists. As a case in point, more than $60 \%$ of the studies of traditional institutions cited in this introductory article were published in 2013 or later. This special issue has provided an opportunity for taking stock of what we have learned about the relationship between traditional institutions and democracy approximately 5 years into this research agenda. However, much additional research is needed. In conclusion, we highlight areas for further investigation that follow from this special issue's motivating questions.

What research do we want to recommend on the compatibility of traditional institutions and modern democratic institutions? This special issue has shown that traditional institutions and modern democratic institutions areas an empirical matter-compatible insofar as they coexist and there are complementarities in their support among citizens. But future research should go beyond this, considering how the various ways that traditional institutions and modern states relate to one another can advance or hinder democracy, individual rights, and material well-being.

Whether incompatibilities appear and have problematic consequences depends obviously on context: We observe great variation in the shares of traditional population, from less than 2 to more than $90 \%$, with implications for their political significance. Furthermore, we observe great variation not only in the types of regimes in which traditional institutions exist but also in their internal organization. Finally, we observe variation in the constitutionalization of traditional institutions (Holzinger et al., 2019), which is in itself an indicator of the intention to make traditional and state institutions compatible. There is thus ample room for future empirical research to address the contextual variation. One step in this direction has been taken by Henn 
(2018), who examines how the integration of chiefs into national institutions influences the relationship between traditional and state authorities at the local level. If chieftaincy structures are integrated into the state, local chiefs are stronger where the state has more presence, but if chieftaincy structures are not integrated into the state, local chiefs are stronger where the state is weak. However, many additional questions about the effects of legal integration on democracy and accountability remain. Does legal integration of traditional institutions affect democratic features such as the implementation of political rights? How does legal integration interact with traditional population size to influence the level of democracy in a country?

More theoretical work is needed to evaluate the compatibility of traditional and democratic institutions, and the conditions under which (in)compatibilities may appear and lead to negative (positive) consequences. Rationalist institutional theories of fit, coherence, and complementarity (e.g., Hall \& Soskice, 2001; Young, 2002, 2008) could provide a starting point. Behr (2017) discusses three mechanisms that are important for avoiding institutional misfit between traditional polities and democratic states: legal certainty, participation, and accountability. Addressing the criticisms outlined in Framework I, legal integration at the state level seems a way of creating institutional coherence either by harmonizing state and customary law, regulating norm conflict (e.g., gender roles, property rights) by providing collision rules, or by granting and delineating spheres of autonomy and responsibility to traditional institutions. As for Framework II, while traditional clientelism may be judged as a threat to democracy - but is not alien to modern democracy - traditional polities may compensate for it by complementary forms of nonelectoral participation and accountability. Regarding Framework III, we argue that alternatives to electoral accountability in traditional governance are worth studying in more detail. Age-set systems, for example, provide for a regular change in leadership positions; councils and assemblies provide constraints on leaders. At least at the lowest level, traditional governance is typically inclusive and accessible, enabling deliberation in village assemblies and emphasizing the principle of consensus. Whereas some traditional kingdoms are clearly autocratic, other traditional polities come closer to modern ideals of participatory and deliberative democracy.

What research do we want to recommend on a framework for understanding the performance of traditional institutions? In this special issue, we have emphasized the limitations of understanding the authority and performance of traditional institutions through the lens of electoral accountability. The quality of leadership by traditional authorities, whether in comparison to each other or to other authorities, does not appear well explained by the degree to which they are selected through 
periodic competitive elections. The question then is whether there is another theoretical framework that can provide a unifying explanation for the performance of these institutions. We have emphasized the importance of the inclusivity of decision-making processes within traditional political institutions and the strength of traditional leaders' connections to their communities, but we do not have enough evidence to propose a unifying theory at this point. Future research should consider the explanatory power of these variables in other contexts.

As an additional avenue for future research, we suggest considering whether democratic processes beyond elections might help explain the quality of traditional institutions. Although competitive multiparty elections have special status in contemporary theories of democratic accountability, theories of deliberative democracy and descriptive representation propose different conditions for obtaining high-quality representation and leadership. Building on our hypothesis that the accountability of traditional political institutions depends on inclusive decision-making processes and strong connections between traditional leaders and their constituents, this is where we would recommend more research. We think theorists of deliberative democracy are likely to identify promising conditions for accountability in traditional institutions, such as usos y costumbres, that involve participatory assemblies (Magaloni et al., 2019). Similarly, scholars who emphasize the importance of descriptive representation would recognize both important challenges and opportunities in traditional political institutions. Traditional leaders are overwhelmingly male, posing a challenge. However, in contrast to many elected leaders, they are usually from the geographic areas they represent and often engage in the same economic sectors as their constituents, presenting an opportunity. If this line of research bears fruit, traditional institutions - both in practice and in theory-might be more compatible with aspects of democracy than earlier generations of scholars believed.

\section{Acknowledgments}

We thank Clara Neupert-Wentz, Sven-Patrick Schmid, Axel Bayer, Daniela Behr, and Roos Haer for supporting the data collection and analysis. We thank Lindsay Benstead, Florian Kern, Carolyn Logan, Virginia Oliveros, and Peter van Der Windt for providing feedback on earlier drafts.

\section{Declaration of Conflicting Interests}

The authors declared no potential conflicts of interest with respect to the research, authorship, and/or publication of this article. 


\section{Funding}

The authors disclosed receipt of the following financial support for the research, authorship, and/or publication of this article: We thank the German Research Foundation (DFG) for funding the Reinhart Koselleck Project "Traditional Governance and Modern Statehood" (grant no. HO 1811/10-1).

\section{ORCID iDs}

Kate Baldwin (iD) https://orcid.org/0000-0001-7256-0312

Katharina Holzinger (iD) https://orcid.org/0000-0003-2917-4744

\section{Notes}

1. For a similar definition, see Holzinger, Kern, and Kromrey (2016).

2. These data are from the Reinhart Koselleck Project "Traditional Governance and Modern Statehood." The project created two distinct datasets: the TradGov Constitutional dataset and the TradGov Group dataset. Both are not yet published but are available upon request from Holzinger. We acknowledge support by Clara Neupert-Wentz, Sven-Patrick Schmid, Axel Bayer, Daniela Behr, and Roos Haer in data collection and analysis.

3. According to Kymlicka (1996) and Banting and Kymlicka (2006), ethnic groups can be divided into three categories, based on three "sources of multiculturalism": national minorities, immigrants, and indigenous ethnic groups. As we would not expect to find traditional political institutions that legitimately coexist with state institutions among national minorities and immigrants, only indigenous ethnic groups are of interest in our context.

4. The most important sources were the Encyclopedia Britannica, CIA World Factbook, UN and World Bank data, Ethnologue (https://www.ethnologue .com/), EPR, and AMAR, and specific websites, such as the Minority Rights Group International (https://minorityrights.org/).

5. The experts were provided with our definition of traditional political institutions and a variety of examples to get consistent assessments of the contemporary existence of traditional institutions.

6. http://www.systemicpeace.org/polityproject.html; https://freedomhouse.org/

7. The variables "traditionally organized population" and "constitutional provisions" are correlated at $r=.485$.

8. Experts came mainly from academia (59\%), nongovernmental organizations $(12 \%)$, public sector employees (7\%), and group members or leaders $(15 \%)$.

9. Of the groups, $3 \%$ are from North America, $18 \%$ from Latin America, $5 \%$ from Europe and Central Asia, 46\% from sub-Saharan Africa, 2\% from North Africa and the Middle East, $11 \%$ from South Asia, and 19\% from East Asia and the Pacific.

10. The experts were aggregated per group, using a manual aggregation technique whereby we corrected obvious inconsistencies. We do not double count if several experts for the same group tick the same box. 
11. http://www.afrobarometer.org/

12. Small differences in numbers should not be overestimated, however, as the country basis for the questions differs: the traditional leader question was not asked in nine out of the 32 countries.

13. For evidence on how traditional authorities compare with citizens, see Voors et al. (2018). For a comparison of donations to traditional institutions versus educational institutions, see Goist and Kern (2018).

\section{References}

Acemoglu, D., Reed, T., \& Robinson, J. A. (2014). Chiefs: Economic development and elite control of civil society in Sierra Leone. Journal of Political Economy, 122, 319-368.

Aldashev, G., Chaara, I. Platteau, J-P., \& Wahhaj, Z. (2012). Formal law as a magnet to reform custom. Economic Development and Cultural Change, 60, 795-828.

Baldwin, K. (2013). Why vote with the chief? Political connections and public goods provision in Zambia. American Journal of Political Science, 57, 794809.

Baldwin, K. (2014). When politicians cede control of resources: Land, chiefs, and coalition-building in Africa. Comparative Politics, 46, 253-271.

Baldwin, K. (2016a). Hereditary rule in democratic Africa: Reconciling citizens and chiefs. In M. Ndulo \& M. Gazibo (Eds.), Growing democracy in Africa: Elections, accountable governance and political economy (pp. 199-218). New Castle Upon Tyne, UK: Cambridge Scholars.

Baldwin, K. (2016b). The paradox of traditional leaders in democratic Africa. Cambridge, UK: Cambridge University Press.

Baldwin, K. (2019). Elected MPs, traditional chiefs, and local public goods: Evidence on the role of leaders in co-production from rural Zambia. Comparative Political Studies, 52, 1925-1956.

Baldwin, K., Muyengwa, S., \& Mvukiyehe, E. (2016). Reforming village-level governance via horizontal pressure? Evidence from an experiment in Zimbabwe (World Bank Working Paper). Retrieved from http://documents.worldbank.org /curated/en/652451484165805083/pdf/WPS7941.pdf

Baldwin, K., \& Mvukiyehe, E. (2015). Elections and collective action: Evidence from changes in traditional institutions in Liberia. World Politics, 67, 690-725.

Banting, K., \& Kymlicka, W. (2006). Multiculturalism and the welfare state: Recognition and redistribution in contemporary democracies. Oxford: Oxford University Press.

Barro, R. (1973). The control of politicians: An economic model. Public Choice, 14, 19-42.

Beath, A., Christia, F., \& Enikolopov, R. (2013a). Do elected councils improve governance? Experimental evidence on local institutions in Afghanistan (MIT Political Science Department Research Paper). Retrieved from http://documents.world bank.org/curated/en/790321468189865207/pdf/WPS6510.pdf 
Beath, A., Christia, F., \& Enikolopov, R. (2013b). Empowering women through development aid: Evidence from a field experiment in Afghanistan. American Political Science Review, 107, 540-557.

Behr, D. M. (2017). Traditional institutions of governance-Friend or foe of development ( $\mathrm{PhD}$ dissertation). University of Konstanz, Konstanz, Germany.

Besley, T., \& Burgess, R. (2002). The political economy of government responsiveness: Theory and evidence from India. The Quarterly Journal of Economics, 117, 1415-1451.

Birnir, J. K., Wilkenfeld, J., Fearon, J. D., Laitin, D. D., Gurr, T. R, Brancati, D., Saideman, S. M., Pate, A., \& Hultquist, A. S. (2015): Socially relevant ethnic groups, ethnic structure, and AMAR. Journal of Peace Research, 52, 110-115.

Cederman, L.-E., Wimmer, A., \& Min, B. (2010). Why do ethnic groups rebel? New data and analysis. World Politics, 62, 87-119.

Chanock, M. (1985). Law, custom, and social order: The colonial experience in Malawi and Zambia. Cambridge, UK: Heinemann.

Charrad, M. M. (2001). States and women's rights: The making of postcolonial Tunisia, Algeria, and Morocco. Berkeley: University of California Press.

Cooper, J. (2018). State capacity and gender inequality: Experimental evidence from Papua new Guinea. New York, NY: Columbia University.

Cruise, O., \& Brien, D. B. (1971). The Mourides of Senegal: The political and economic organization of an Islamic brotherhood. Oxford: Oxford University Press.

D'Aoust, O., \& Sterck, O. (2016). Who benefits from customary justice? Rentseeking, bribery and criminality in sub-Saharan Africa. Journal of African Economies, 25, 439-467.

De Kadt, D., \& Larreguy, H. A. (2018). Agents of the regime? Traditional leaders and electoral clientelism in South Africa. Journal of Politics, 80, 382-399.

Díaz-Cayeros, A., Magaloni, B., \& Ruiz-Euler, A. (2014). Traditional governance, citizen engagement, and local public goods: Evidence from Mexico. World Development, 53, 80-93.

Englebert, P. (2002). Born-again Buganda or the limits of traditional resurgence in Africa. Journal of Modern African Studies, 40, 345-368.

Fearon, J. D. (1999). Electoral accountability and the control of politicians: Selecting good types versus sanctioning poor performance. In A. Przeworski, S. C. Stokes, \& B. Manin (Eds.), Democracy, accountability, and representation (pp. 55-97). New York, NY: Cambridge University Press.

Ferejohn, J. (1986). Incumbent performance and electoral control. Public Choice, 2, $5-25$.

Goist, M., \& Kern, F. G. (2018). Traditional institutions and social cooperation: Experimental evidence from the Buganda Kingdom. Research and Politics, 5, $1-9$.

Gottlieb, J. (2017). Explaining variation in broker strategies: A lab-in-the-field experiment in Senegal. Comparative Political Studies, 50, 1556-1592.

Hall, P. A., \& Soskice, D. (2001). Varieties of capitalism: The institutional foundations of comparative advantage. Oxford: Oxford University Press. 
Hariri, J. G. (2012). The autocratic legacy of early statehood. American Political Science Review, 106, 471-494.

Henley, D., \& Davidson, J. S. (2008). In the name of Adat: Regional perspectives on reform, tradition, and democracy in Indonesia. Modern Asian Studies, 42, 815-852.

Henn, S. (2018). Complements or substitutes: State presence and the power of traditional leaders. Cambridge, MA: Harvard University.

Holzinger, K., Haer, R., Bayer, A., Behr, D., \& Neupert-Wentz, C. (2019). The constitutionalization of indigenous group rights, traditional political institutions, and customary law. Comparative Political Studies, 52, 1775-1809.

Holzinger, K., Kern, F. G., \& Kromrey, D. (2016). The dualism of contemporary traditional governance and the state: Institutional setups and political consequences. Political Research Quarterly, 69, 469-481.

Holzinger, K., Kern, F. G., \& Kromrey, D. (2017). Traditional institutions in subSaharan Africa: Endangering or promoting stable domestic peace? Forschung $D S F$. Retrieved from https://bundesstiftung-friedensforschung.de/wp-content /uploads/2017/09/Forschungsbericht-42.pdf

Honig, L. (2019). The struggle for land in Africa: The state, customary authorities and citizens. Boston, MA: Boston College.

Huntington, S. (1968). Political order in changing societies. New Haven, CT: Yale University Press.

Jochem, T., Murtazashvili, I., \& Murtazashvili, J. (2016). Establishing local government in fragile states: Experimental evidence from Afghanistan. World Development, 77, 293-310.

Keefer, P., \& Vlaicu, R. (2008). Democracy, credibility and clientelism. The Journal of Law, Economics, \& Organization, 24, 371-406.

Kymlicka, W. (1996). Multicultural citizenship: A liberal theory of minority rights. New York: Oxford University Press.

Koter, D. (2013). King makers: Local leaders and ethnic politics in Africa. World Politics, 65, 187-232.

Kramon, E. (2017). Ethnic group institutions and electoral clientelism. Party Politics, $25,435-447$.

Lemarchand, R., \& Legg, K. (1972). Political clientelism and development: A preliminary analysis. Comparative Politics, 4, 149-178.

Lemerchand, R. (1972). Political clientelism and ethnicity in Tropical Africa: Competing solidarities in nation-building. American Political Science Review, 66, 68-90.

Lerner, D. (1958). The passing of traditional society: Modernizing the Middle East. New York, NY: Free Press.

Logan, C. (2009). Selected chiefs, elected councilors and hybrid democrats: Popular perspectives on the co-existence of democracy and traditional authority. The Journal of Modern African Studies, 47, 101-128.

Logan, C. (2013). The roots of resilience: Exploring popular support for African traditional authorities. African Affairs, 112, 353-376. 
Magaloni,B., Díaz-Cayeros, A., \& Ruiz-Euler, A.(2019).Public good provision and traditional governance in indigenous communities in Oaxaca, Mexico. Comparative Political Studies, 52, 1841-1880. Retrieved from http://cpd.berkeley.edu/wp -content/uploads/2018/01/CPC_Diaz-Cayeros.pdf

Mamdani, M. (1996). Citizen and subject: Contemporary Africa and the legacy of late colonialism. Princeton, NJ: Princeton University Press.

Manin, B., Przeworski, A., \& Stokes, S. (1999). Elections and representation. In A. Przeworski, S. C. Stokes, \& B. Manin (Eds.), Democracy, accountability, and representation (pp. 29-54). New York, NY: Cambridge University Press.

Muriaas, R. L. (2011). Traditional institutions and decentralisation: A typology of co-existence in sub-Saharan Africa. Forum for Development Studies, 38, 87-107.

Muriaas, R. L., Wang, V., Benstead, L., Dulani, B., \& Rakner, L. (2019). Why the gender of traditional authorities matters: Intersectionality and women's rights advocacy in Malawi. Comparative Political Studies, 52, 1881-1924.

Murtazashvili, J. B. (2016). Informal order and the State in Afghanistan. Cambridge, UK: Cambridge University Press.

Ntsebeza, L. (2005). Democracy compromised: Chiefs and the politics of the land in South Africa. Leiden, The Netherlands: Brill.

O'Donnell, G. (1993). On the state, democratization and some conceptual problems: A Latin American view with glances at some post-communist countries. World Development, 21, 1355-1369.

Oomen, B. (2005). Chiefs in South Africa: Law power and culture in the post-apartheid era. Oxford, UK: James Currey.

Osabu-Kle, D. (2000). Compatible cultural democracy: The key to development in Africa. Toronto, Ontario, Canada: University of Toronto Press.

Ranger, T. O. (1983). The invention of tradition in Colonial Africa. In T. O. Ranger \& E. J. Hobsbawm (Eds.), The invention of tradition (pp. 597-612). Cambridge, UK: Cambridge University Press.

Sandefur, J., \& Siddiqi, B. (2013). Delivering justice to the poor: Theory and experimental evidence from Liberia (Working Paper). Retrieved from http://cega .berkeley.edu/assets/cega_events/61/5D_Political_Economy-_Violence.pdf

Schumpeter, J. (1942). Capitalism, socialism and democracy. New York, NY: Harper \& Row.

Scott, J. (1972). Patron-client politics and political change in Southeast Asia. American Political Science Review, 91-113.

Stokes, S. (2007). Is vote buying undemocratic. In F. Schaffer (Ed.), Elections for sale: The causes and consequences of vote buying. Boulder, CO: Lynne Rienner.

Ubink, J. (2008). Traditional authorities in Africa: Resurgence in an era of democratisation. Leiden, The Netherlands: Leiden University Press.

van der Windt, P., Humphreys, M., Medina, L., Timmons, J., \& Voors, M. (2019). Citizen attitudes toward traditional and state authorities: Substitutes or complements? Comparative Political Studies, 52, 1810-1840.

Voors, M., Turley, T., Bulte, E., Kontoleon, A., \& List, J. A. (2018). Chief for a day. Elite capture and management performance: Evidence from a field experiment in Sierra Leone. Management Science, 64, 5461-5959. 
Weber, M. (1958). The three types of legitimate rule. Berkeley Publications in Society and Institutions, 4, 1-11.

Young, O. R. (2002). Fit: Matching ecosystem properties and regime attributes. In O. R. Young (Ed.), The institutional dimensions of environmental change: Fit, interplay, and scale (pp. 55-82). Cambridge: MIT Press.

Young, O. R. (2008). The architecture of global environmental governance: Bringing science to bear on policy. Global Environmental Politics, 8, 14-32.

\section{Author Biographies}

Kate Baldwin is the Peter Strauss Family assistant professor of Political Science at Yale University. Her research examines how traditional and religious institutions affect political accountability in sub-Saharan Africa. Her first book, The Paradox of Traditional Chiefs in Democratic Africa, was published in 2016.

Katharina Holzinger is professor of International Relations at the Department of Politics and Public Administration at the University of Konstanz, Germany. Her research areas include environmental policy, the European Union, negotiation and deliberation, as well as traditional governance in Africa. She has published in journals such as International Organization, European Journal of International Relations, Political Communication, Journal of European Public Policy, European Union Politics, and with Cambridge University Press. 